\title{
Economic \& Trade Interdependence between Taiwan (ROC) and China (PROC)
}

\author{
Frank Tian Xie, Ph.D. \\ John M. Olin Palmetto Chair Professor in Business \\ Associate Professor of Marketing \\ School of Business Administration \\ University of South Carolina Aiken \\ Aiken, South Carolina \\ $\&$ \\ Fellow, Taiwan Fellowship \\ Center for Chinese Studies, ROC National Library \\ $\&$ \\ Visiting Scholar \\ Center for Public Economic Policy Studies \\ National Taiwan University \\ Taipei, Taiwan, ROC \\ Shu-Chen Tsao \\ Department of Economics \\ National Taiwan University, Taipei, Taiwan \\ Visiting Student, Global Study Program \\ University of California at Davis
}

\begin{abstract}
There has been extensive research in the areas of and trade relationships, economic interdependence, and national security in fields such as global studies, security studies, international trade, and global economics. The current research draws from several of the related fields and provides empirical evidence in the context of the opposing forces across Taiwan Strait, and examines the unique geo-political interaction between Taiwan (Republic of China) and China (People's Republic). The study is pertinent during a time when the second power transfer in Taiwan took place and the administration of Tsai Ing-wen faces drastic changes in mainland China and growing tensions between the two. Trade and economic ties between the two entities are becoming even more intriguing as the Unites States, a third party with close ties to both Taiwan and China, is embarking on a new direction under Trump administration and imposing steep tariffs on China. Longitudinal study on trade and investment relationships between 1990 and 2015 presents a shift in interdependency and the intricate nature of the relationship amid geopolitical turmoil. The trends are examined using both trade and investment as parameters and a new measure of integrated bilateral dependency growth rate on the two entities.
\end{abstract}

\section{Introduction}

Transition of democratic political power took place for the second time when President Tsai Ing-wen took office in May of 2016 in Taiwan (Republic of China). The Tsai administration took on a series of reforms while President Xi Jinping of mainland China (PRC) was facing tremendous domestic changes. The political and economic situation in China becomes even more complex today, when a trade war between the U.S. and China is ongoing. During this period of time, the interactions and tensions across Taiwan straits between the two Chinas is also quite contentious, due to the interdependence between the two entities with regard to politics, economy, diplomacy, and military. With Hong Kong and Macao included, the relations among these four players exacerbated with American policies on China and Taiwan are being rewritten and are incorporated in the picture. Studies on economic and trade interdependence between Taiwan (ROC) and China (PRC) is pertinent to the democracy in Taiwan and U.S. interests in Indo-Pacific region, as well as to global business and economy, and regional security. 
This study draws from literature from global economy, global strategy, and global security in an effort to shed light on the bilateral relationship and interdependency for policy makers in Taiwan and America. Taiwan used to have a so-called "Silicon Shield" where the semiconductor sector in Taiwan is a "shield" to Taiwan for any potential attack by China as Taiwan is the key and important player of the industry in the world where an interruption of the supply chain is detrimental to worldwide economy. However, this dependence in favor of Taiwan was sabotaged by mainland China when Taiwanese semiconductor industry moved westbound to mainland China (Chen, 2017).

The anxiety and concern among people of Taiwan is not unsubstantiated. According to a report on Freedom Times, the Communist regime of China has attempted, even quite successfully in some areas, to influence and control Taiwan through engaging 5\% of the population of Taiwan who are pro-quick-unification with China (Freedom Times 2017).

Extensive research has examined the relationship between economic interdependence and international conflict, when two major schools of thoughts emerged, with some researchers suggest that interdependence produces greater international conflict, and others suggest interdependence produces a decline in conflict (McMillan 1997). Still others argue that both schools of thought may be correct: while the costly aspects of interdependence seem to produce greater international conflict, its beneficial aspects appear to produce a decline in conflict (Gasiorowski 1986).

McMillan (1997) and others examined how the costly and beneficial aspects of interdependence combine to affect interstate conflict, and identifiedthe relationships among the various dimensions of interdependence and conflict themselves. Some even argued that rivalry within interdependence is possible (Buszynski 2009). Maoz (2009) integrated "sensitivity interdependence" - the effects of changes in one state on other states - with "vulnerability interdependence" - the opportunity costs of breaking a relationship, and the framework measures interdependence at different levels of analysis and across multiple relationships.

The authors examine such relationship and dependences across Taiwan Strait between Taiwan and China using data from government sources in Taiwan and the United States, and explore the trend and movement over a period of a quarter of a century (between 1990 and 2015), in an effort to understand the intricate relationship between a free China in Taiwan and a Communist China in mainland. Under the current state of a furious trade war between U.S. and China, which greatly affects Taiwan and Taiwanese investors as well, this study is of particular importance to understand the business and trade relations in the most important expanse in the IndoPacific region.

\section{Literature Review}

Blanch et al.(1996) emphasized the strategic goods (i.e., those essential materials for national industry and defense) asmajor concern, whereby they calculated "the strategic good vulnerability" to capture the most strategically important costs of international trading. The Strategic Goods Test(SGT) introduced by Blanch et al. provided an approach to evaluatethe dependence of Taiwan on mainland China for continued and stable access to crucial resources for national survival, and vice versa.

The evaluation of the impact of Cross-Strait Service Trade Agreement (CSSTA) on Taiwan's macroeconomic, conducted by Chung-Hua Institution for Economic Research (2009) offered projected statistics for examining such potential impact on some specific industries, which could be regard as strategically crucial. Therefore, trading of those industries are necessary for extraordinary caution, because of the considerations of the strategically vulnerability in Blanch et al.(1996).

Wang Hua et al.(2010) utilized VectorError Correction Model(VECM) by using vertical auto regression(VAR) quantitative method as an evaluation of the interdependence across the Taiwan Strait. By regressing amount of exports, amount of imports, Taiwanese direct investment (TDI), GDP of Taiwan and GDP of mainland China, they concluded that the investments and trading are important factors for the economic growth of both sides of the strait.

Gomez et al.(2013) distinguished the synchronization in regional growth patterns and the synchronization of the world economy by calculating clustering GDP growth rate. It was shown by Gomez et al. that dynamics of interdependence has been driven more by the regional one. 
Chen Tian-Chih(2003) regarded the recent economic growth of China as a result of Pareto Improvement of resource allocation. Following the Chinese economic reform, the consequent impact of cross-strait trading on Taiwan, according to Chen Tian-Chih, is influential, yet the resource allocation between Taiwan and mainland China is still under the principle of global division of labor.

Wang et al. (王華2013) examined the interdependence between China and Taiwan at three levels: Input, Output, and Affects. Input refers to the interdependence between the two entities at the products and production factor level; Output refers to the interdependence at the production, demand, price, and employment level; and the Affect refers to interdependence between the two at the level of economic structure, social structure, and government policies. Their study used many quantitative measures for interdependency such as trade interdependency (that can be subdivided into export interdependency and import interdependency), dependency of mainland China on Taiwan businesses, strength of bilateral trade between Taiwan and China, regression coefficients of bilateral trade, and elasticity index of bilateral trade. Wang's calculations were based on trade volume, GDP, and trade growth as the denominators, corresponding to "trade volume", "direct economic impact", and "overall economy".

Trade relations between Taiwan and China

In this study, we collected data from the Overseas Chinese and Foreign Investment Commission of the Ministry of Economic Affairs of ROC, Customs Administration of the Ministry of Finance, and the World Bank. Adopting the quantitative model of Wang et al. (2013) and then further developed it, we analyzed the data using static analysis on the interdependency, and factored the transition of power and world affairs as the background.

1. Trade Interdependence based on Trade Volume

Based on trade volume (with total trade as the denominator), the dependence of Taiwan on trade with China is on the rise in the past 25 years, as illustrated in Figure 1.

Figure 1. Taiwan's Dependence on Bilateral Trade with China

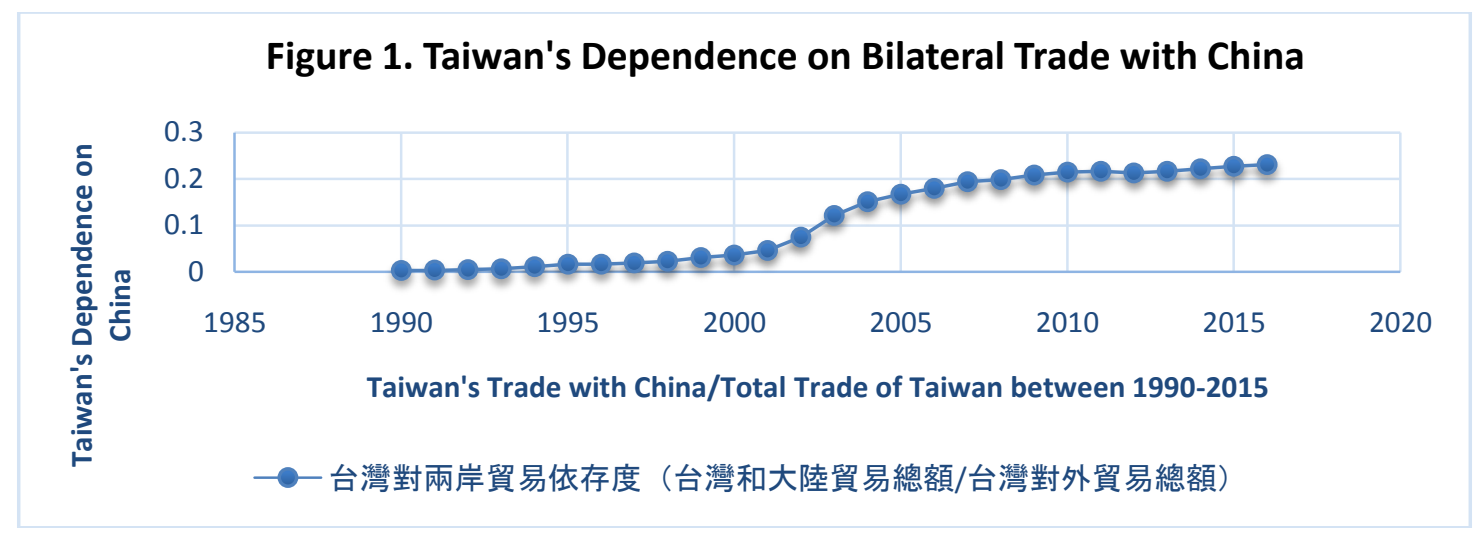

Figure 2. Total Trade between Taiwan and China

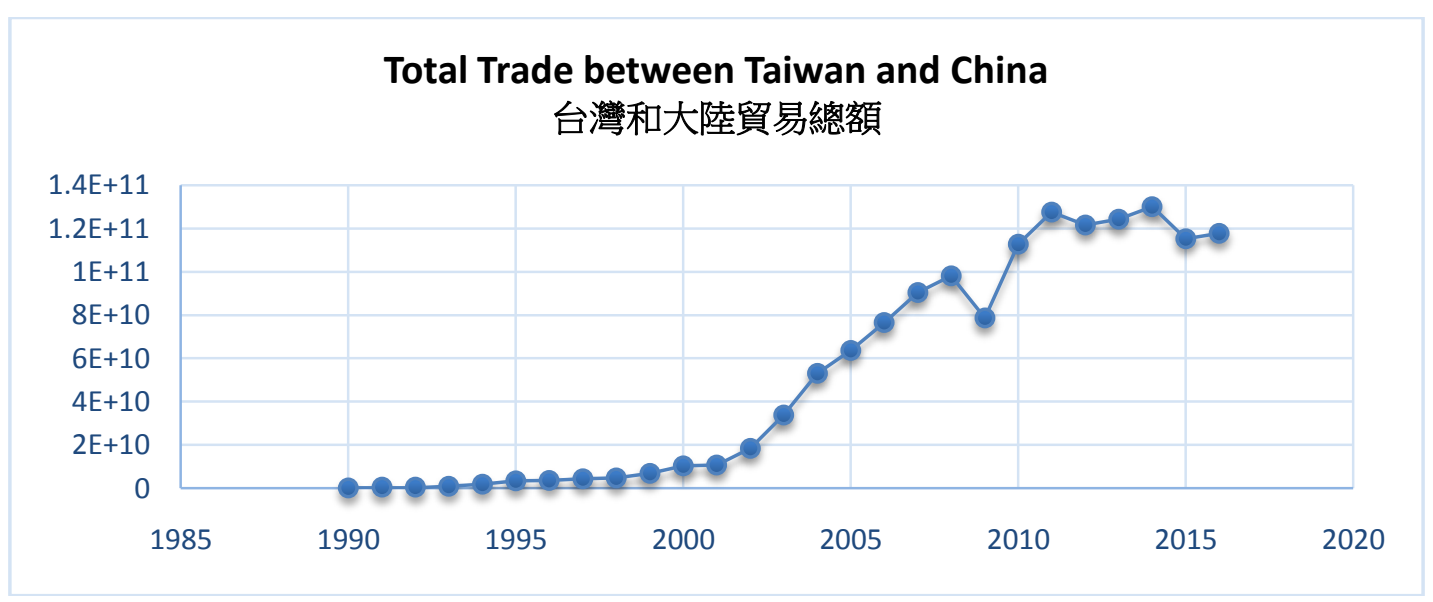


Both the total trade of Taiwan with China and total trade of Taiwan overall (Figure 2 and 3) experienced significant downward movements in 2009. It is estimated that the financial crisis of 2008 in the United States led to worldwide recession and this is reflected in the decreased GDP for both countries. Yet the ratio of the two parameters largely diminished the fluctuation in their own magnitude, as shown in the figures.

Figure 3. Total Foreign Trade of Taiwan

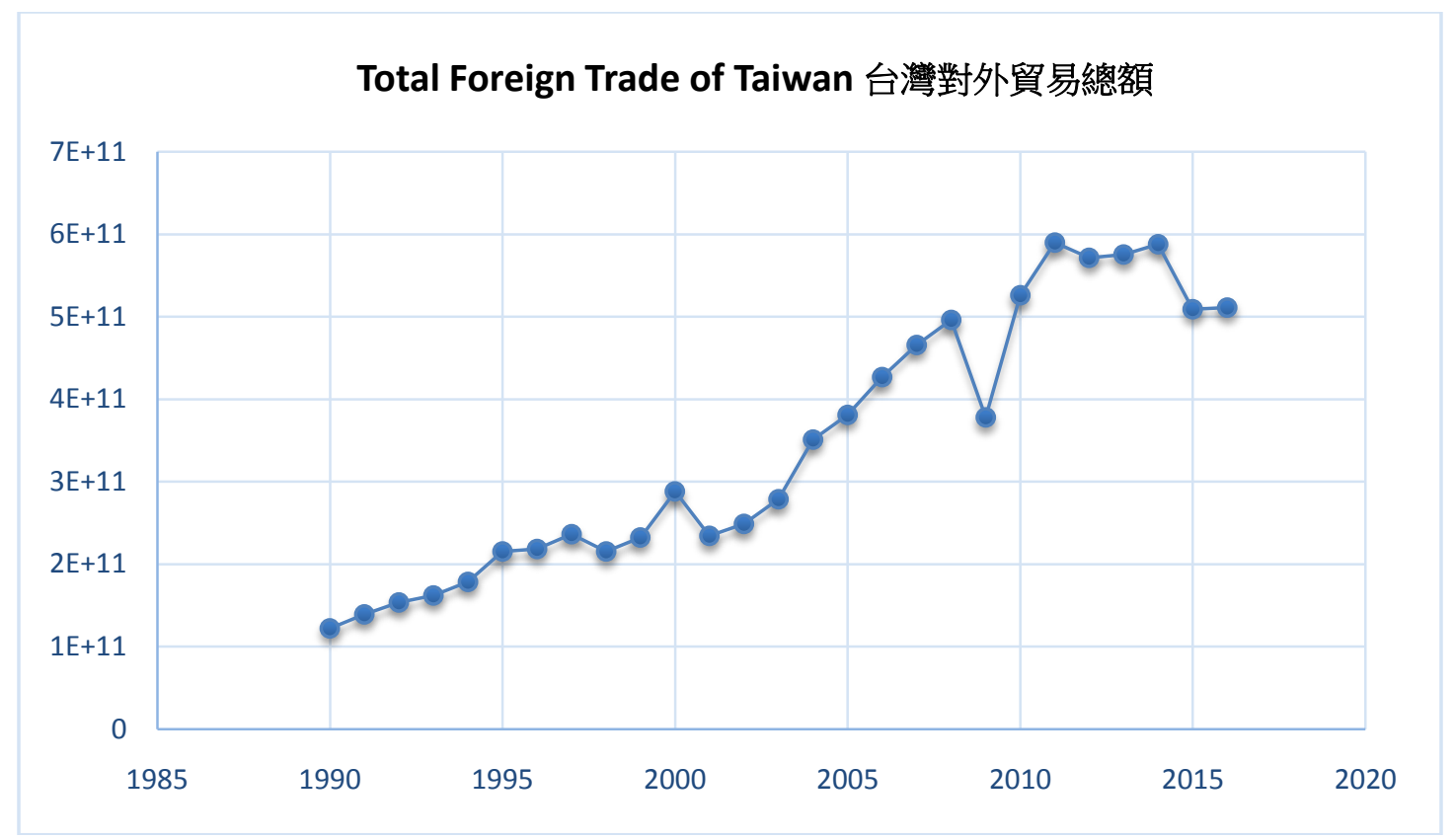

(Units: USD)

Figure 4. Export and Import Dependency

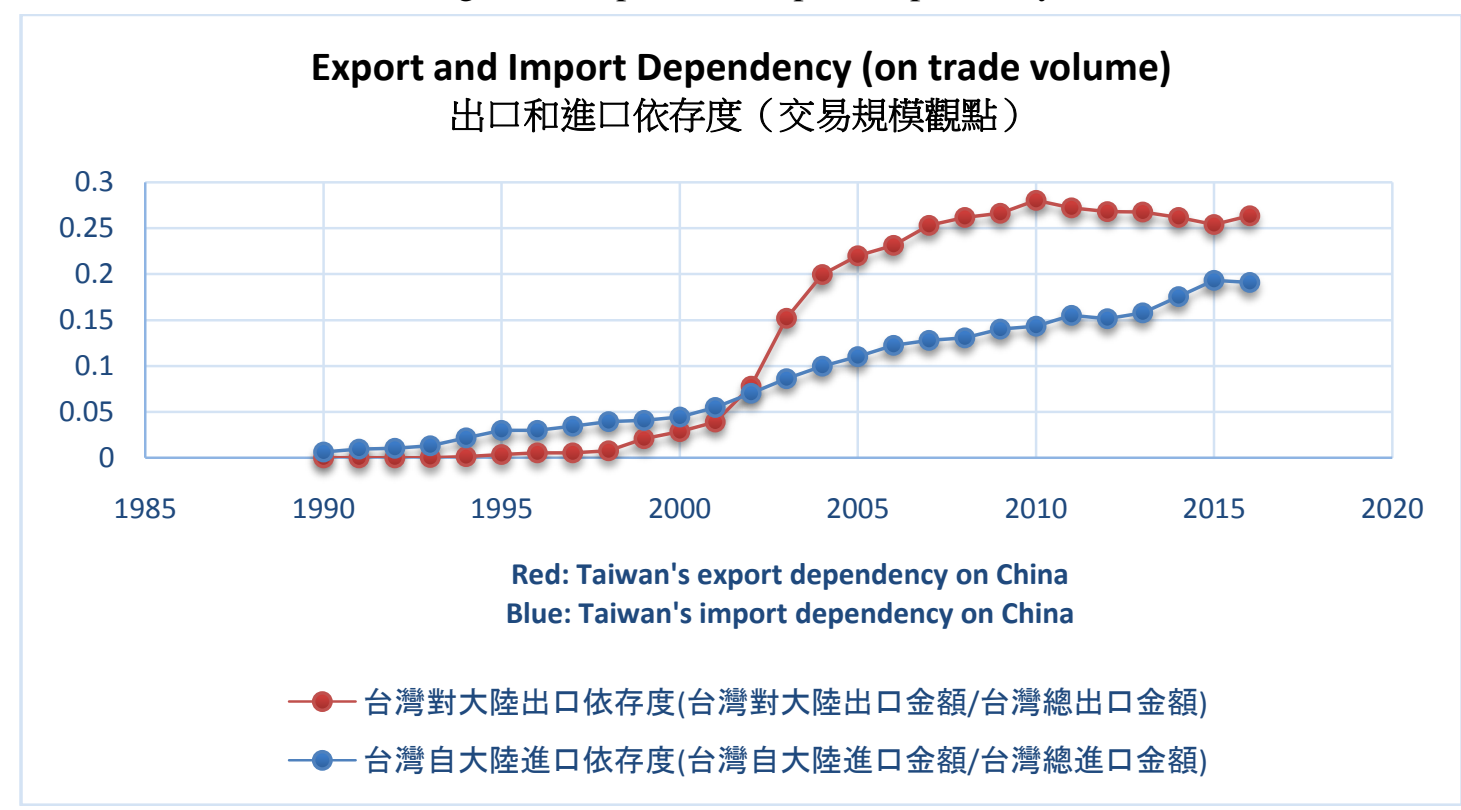

As well, the two parameters (total trade between Taiwan and China, and total foreign trade of Taiwan) have a high correlation coefficient of 0.9828855 , demonstrating that the two grow almost in parallel over the years.

However, if trade dependency is divided into export dependency and import dependency (Figure 4), we will see that export dependency of Taiwan on China grows at a faster pace than import dependency.

2. Investment Dependency (Transaction volume view) 
Figure 5. Taiwanese investment in China (US dollars)

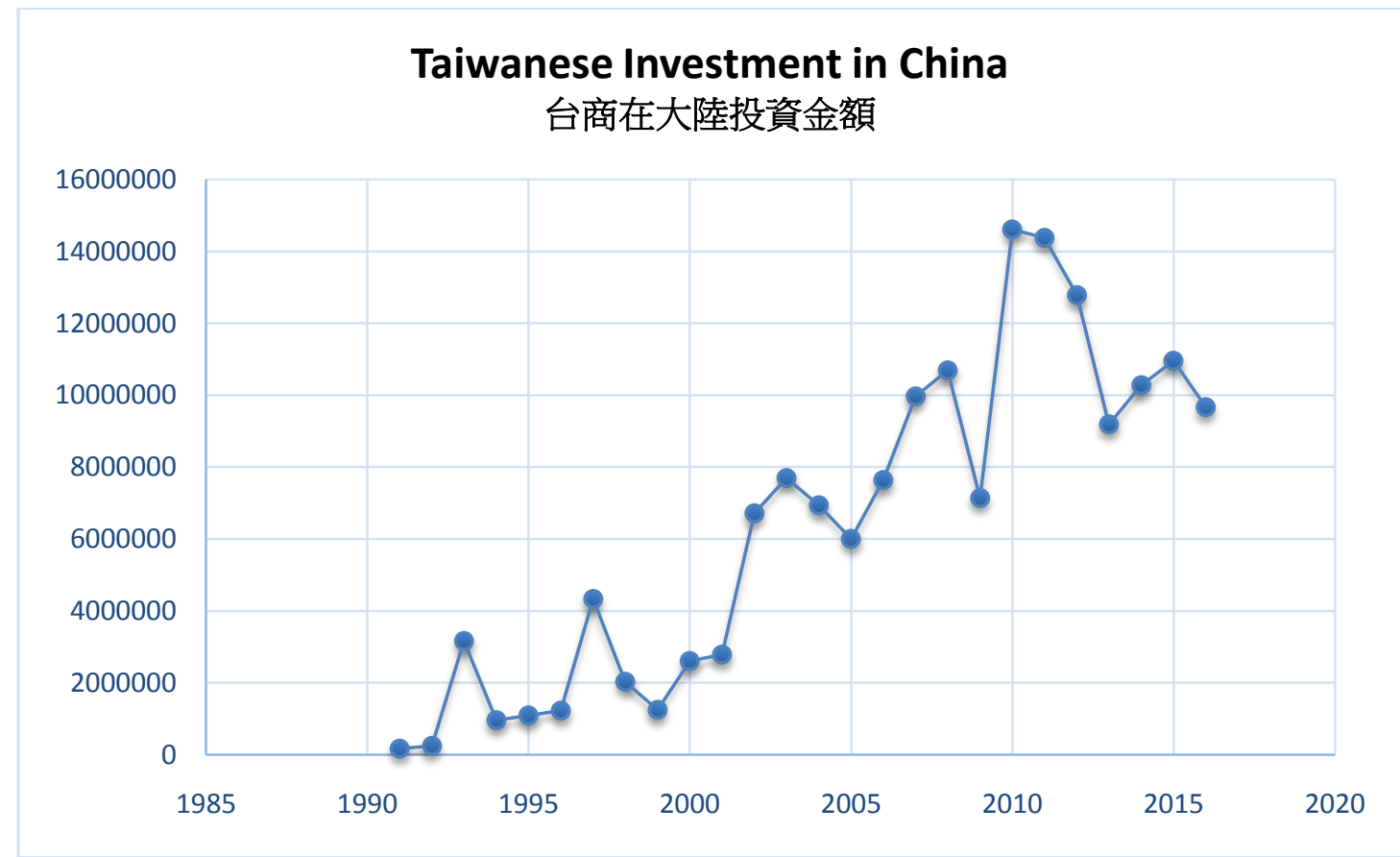

In investment, even though Taiwanese investment in China and mainland Chinese investment in Taiwan (Figure 5 and Figure 6) both see increases in the long run, but compared with trade, short term fluctuations in investment is much larger and varied tremendously from time to time.

Figure 6. Mainland Chinese investment in Taiwan (USD)

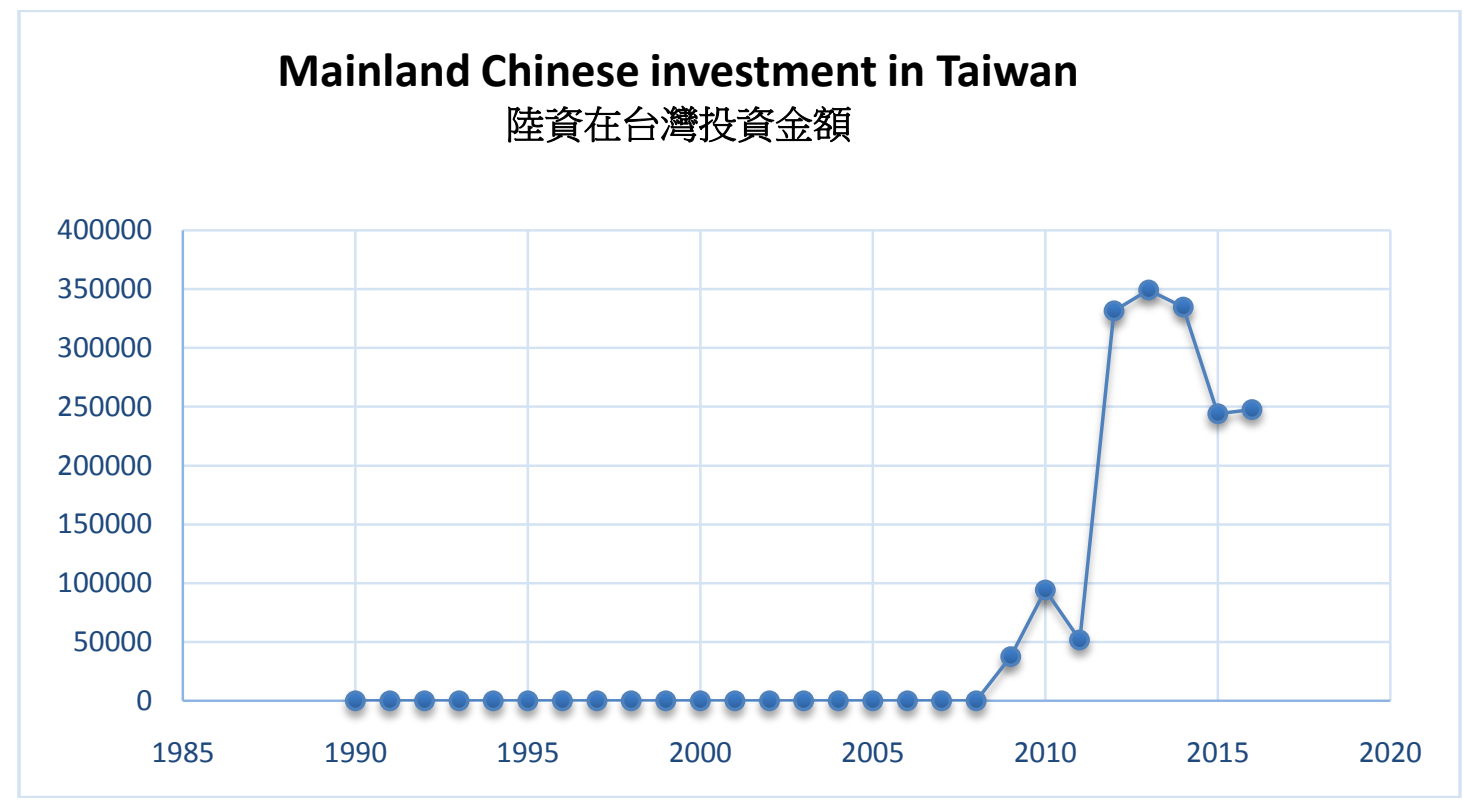

As to the mainland China's dependency on Taiwanese investment, even though the total investment is increasing, the dependency of China on Taiwanese investment over the long term sees no significant growth, especially after 2005 , as the dependency fell to the level of that of the 1990's.Even though the investment pool of fund of Taiwan is relatively smaller, yet the dependency of Taiwan on Chinese investment, on average, is less than the dependency of China on Taiwanese investment (Figure 7). (Note that Taiwan only became open to Chinese investment in July of 2009). 
Figure 7. Taiwanese and Chinese investment dependencies

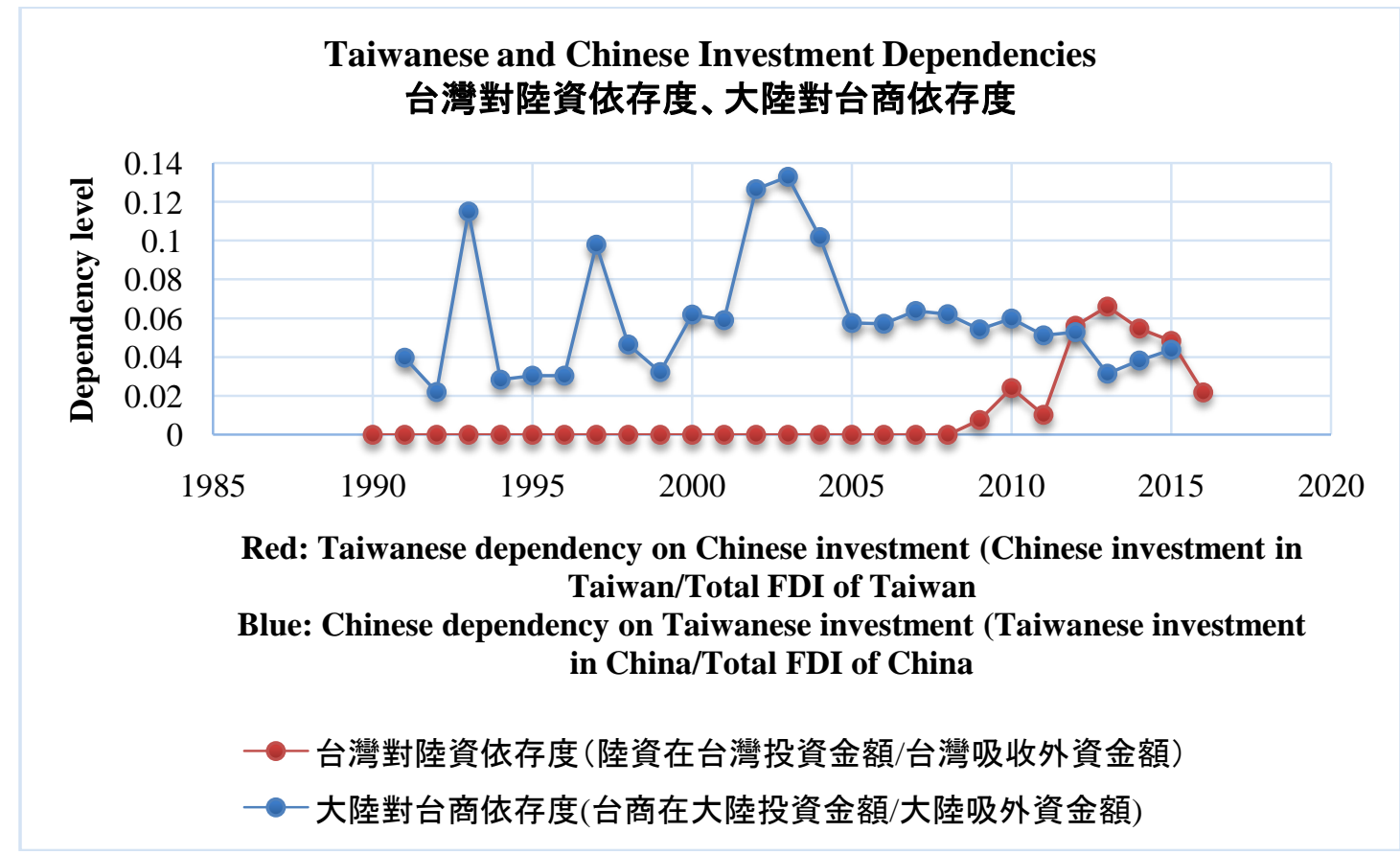

After 2005, Chinese dependency on Taiwanese investment saw a drastic decline, as this was the time when mainland China started to absorb large amount of investment from regions or countries other than Taiwan (Figure 8).

Figure 8. FDI in China: from Taiwan and elsewhere. (USD)

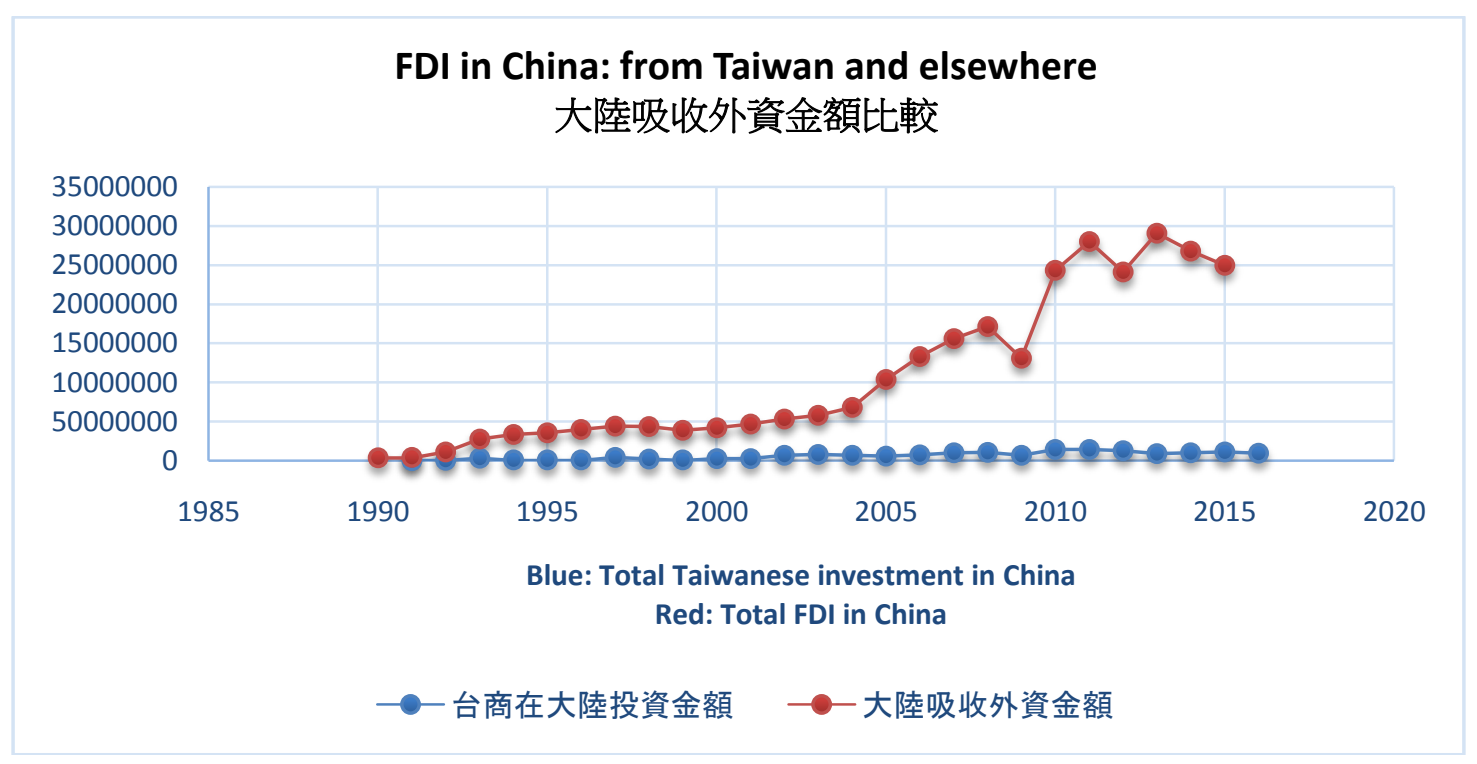

\section{Trade Dependency of Taiwan (based on Direct Economic Impact)}

The Direct Economic Impact view uses GDP as the denominator in calculating the trade dependencies. For Taiwan, nominal GDP growth over the long term between 1990 and 2015 is generally on the rise, with smallscale downward trends in 1998, 2001, and 2009 (Figure 9). 


\section{Figure 9. Nominal GDP of Taiwan (in million USD)}

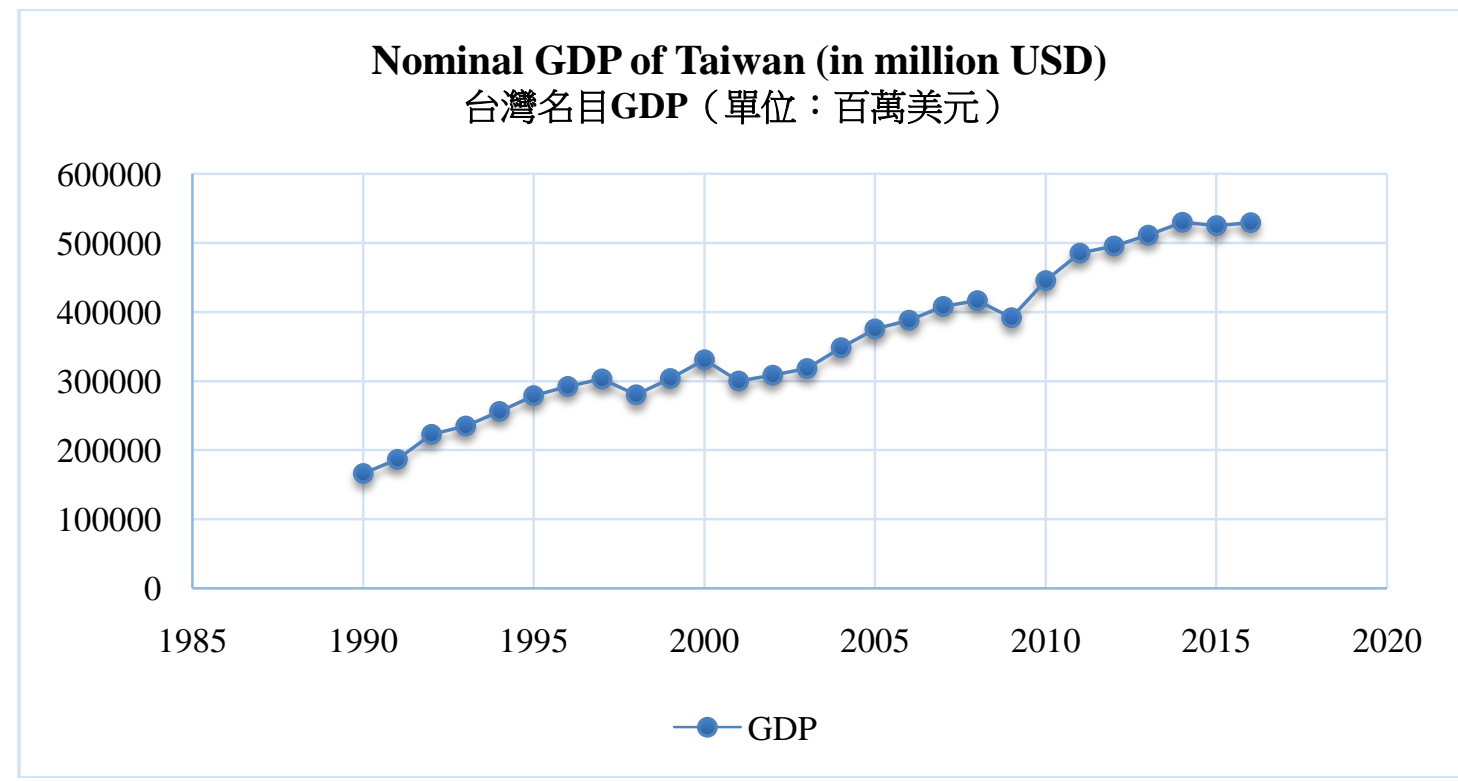

Looking at the direct economic impact, Taiwan's dependency on trade with China presents some interesting trends (Figure 10). Around the period of the aftermath of the financial crisis in 2009, decline in bilateral trade between Taiwan and China saw a steeper rate than the decline of GDP of Taiwan, therefore, the trade dependence decreased significantly.

Figure 10. Taiwan's dependence on bilateral trade.

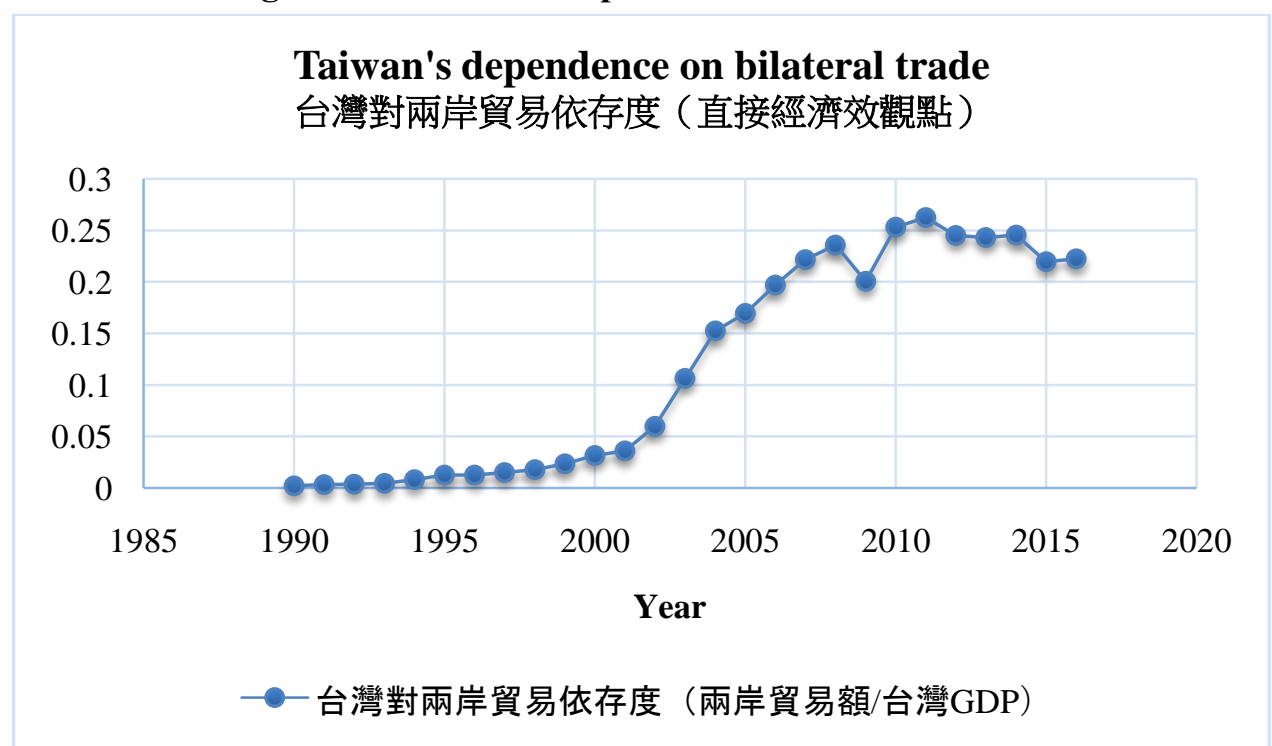

Comparing the two methods of calculating the bilateral trade dependency (Figure 11),it is obvious that the trend is more apparent when GDP is used as the denominator. That is, in 2009, Taiwan's overall foreign trade declined, and the magnitude of the decline roughly equals that of the decline in bilateral trade between Taiwan and China. Taiwan's dependence on bilateral trade, when using two different methods as bases for calculation, yields similar results. In Figure 11, the GDP of Taiwan and total foreign trade of Taiwan are quite close (Table 1). The two do not seem to be having any causal relationship, based on the way they are calculated. 
Table 1. Taiwan's Total Trade and GDP $(\mathbf{1 9 9 0 - 2 0 1 6 )}$

\begin{tabular}{|c|c|c|}
\hline Year & Taiwan's Total Trade(USD) & GDP(million USD ) \\
\hline 1990 & $121,929,180,127$ & 166,615 \\
\hline 1991 & $139,037,626,044$ & 187,314 \\
\hline 1992 & $153,471,129,436$ & 223,159 \\
\hline 1993 & $162,150,753,782$ & 235,140 \\
\hline 1994 & $178,383,464,497$ & 256,404 \\
\hline 1995 & $215,203,771,718$ & 279,224 \\
\hline 1996 & $218,307,063,978$ & 292,665 \\
\hline 1997 & $236,499,793,289$ & 303,737 \\
\hline 1998 & $215,241,158,169$ & 280,369 \\
\hline 1999 & $232,272,734,338$ & 304,171 \\
\hline 2000 & $288,321,181,753$ & 331,452 \\
\hline 2001 & $234,279,376,023$ & 300,450 \\
\hline 2002 & $248,550,493,475$ & 308,875 \\
\hline 2003 & $278,602,202,715$ & 318,590 \\
\hline 2004 & $351,114,338,847$ & 348,479 \\
\hline 2005 & $381,034,544,003$ & 375,769 \\
\hline 2006 & $426,707,794,911$ & 388,589 \\
\hline 2007 & $465,921,799,289$ & 408,254 \\
\hline 2008 & $496,069,221,607$ & 416,961 \\
\hline 2009 & $378,038,242,624$ & 392,065 \\
\hline 2010 & $525,829,376,825$ & 446,105 \\
\hline 2011 & $589,687,272,874$ & 485,653 \\
\hline 2012 & $571,645,967,108$ & 495,845 \\
\hline 2013 & $575,330,472,707$ & 511,614 \\
\hline 2014 & $587,713,863,075$ & 530,519 \\
\hline 2015 & $508,999,362,766$ & 525,196 \\
\hline 2016 & $510,880,771,912$ & 529,910 \\
\hline
\end{tabular}

Figure 11. Comparison of Trade Dependence using both methods

Taiwan's dependence on bilateral trade: comparison of both methods 台灣對兩岸貿易依存度：兩種觀點比比較

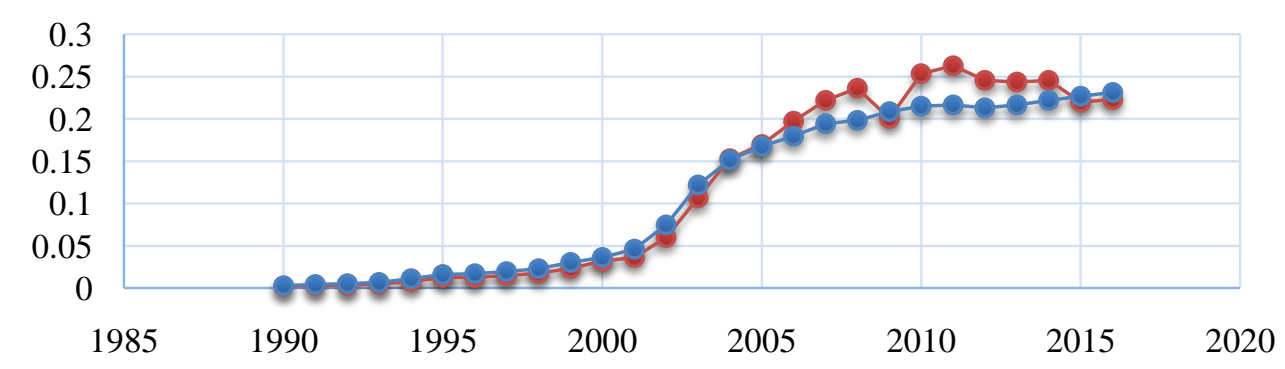

Red: Taiwan's dependence on bilateral trade (Total trade/GDP of Taiwan) Blue: Taiwan's dependence on bilateral trade (Total trade/Total foreign trade of Taiwan)

一一台灣對兩岸貿易依存度（兩岸貿易額/台灣GDP）

- 一台灣對兩岸貿易依存度（兩岸貿易額/台灣對外貿易總額） 
Taiwan's GDP: =Domestic Consumption + Government Spending + Investment + Export - Import

Taiwan's Foreign Trade:=Export + Import

4. Trade Dependency of Mainland China (Direct Economic Impact)

Based on data from the World Bank, GDP of mainland China has been on an accelerated rise since 1990 (Figure 12).While Chinese economy was on the rise between 1990 and 2015, China's dependency on bilateral trade with Taiwan did not increase over the years (Figure 13). Beginning in 2005, the dependency was actually in decline. The result echoes that of downward trend discussed previously with regard to China's dependency on Taiwanese investment.

Figure 12. Nominal GDP of mainland China (million USD)

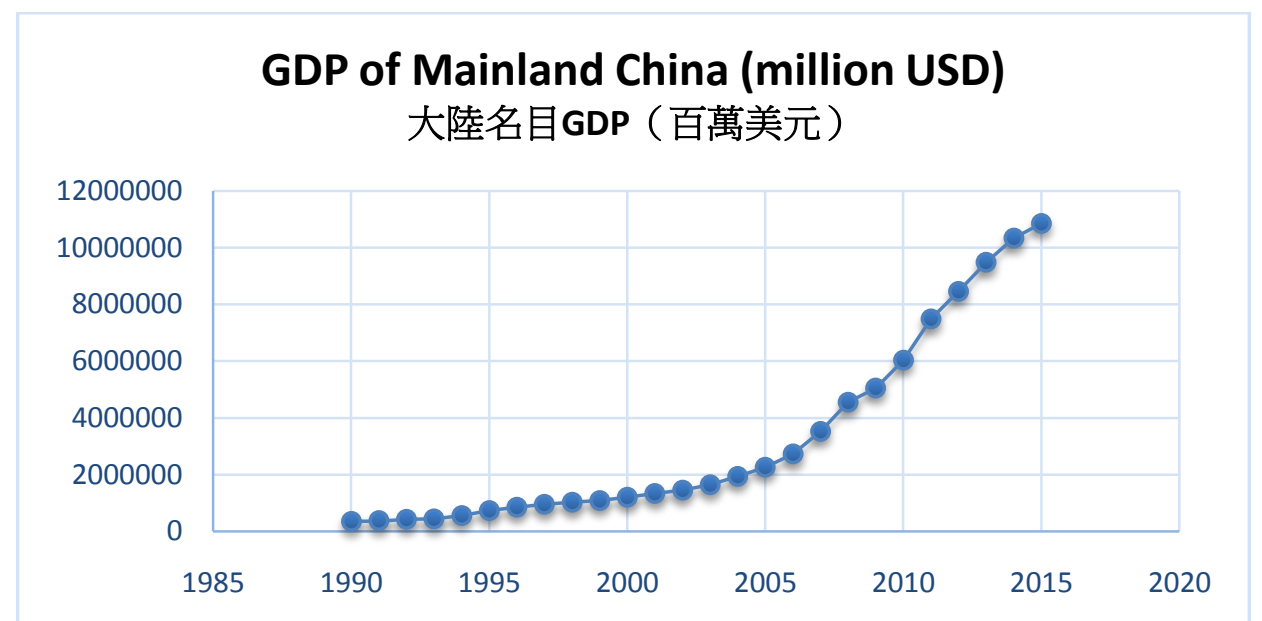

Figure 13. China's Dependency on Bilateral Trade (direct economic impact)

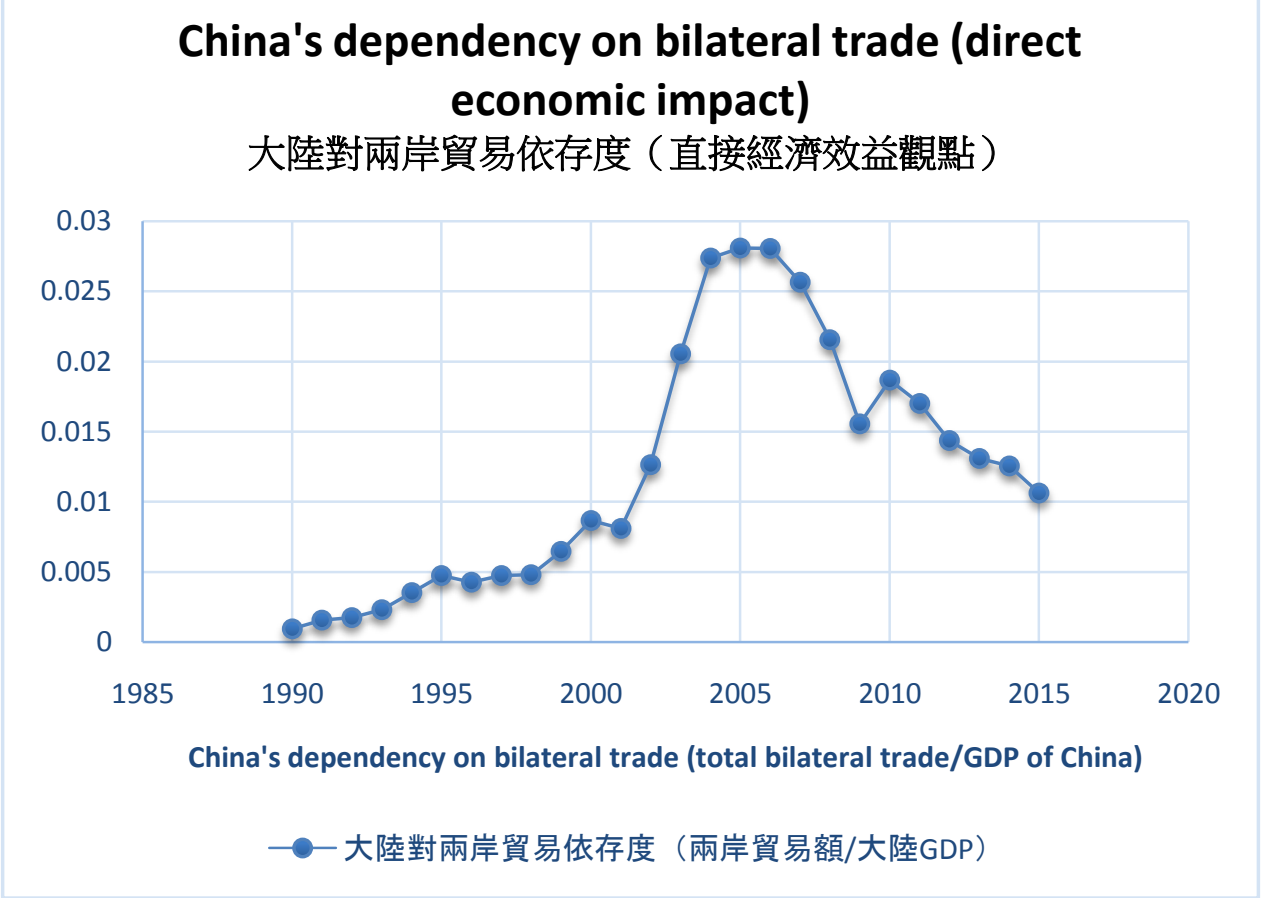

If we compare the trade dependencies of Taiwan and China on the bilateral trade between the two (Figure 14), we will find that Taiwan's dependency is much higher than that of China. In recent years, the bilateral trade between the two countries has approached to about $30 \%$ of the GDP of Taiwan. 
Figure 14. Comparison of Trade Dependency of Taiwan and China.

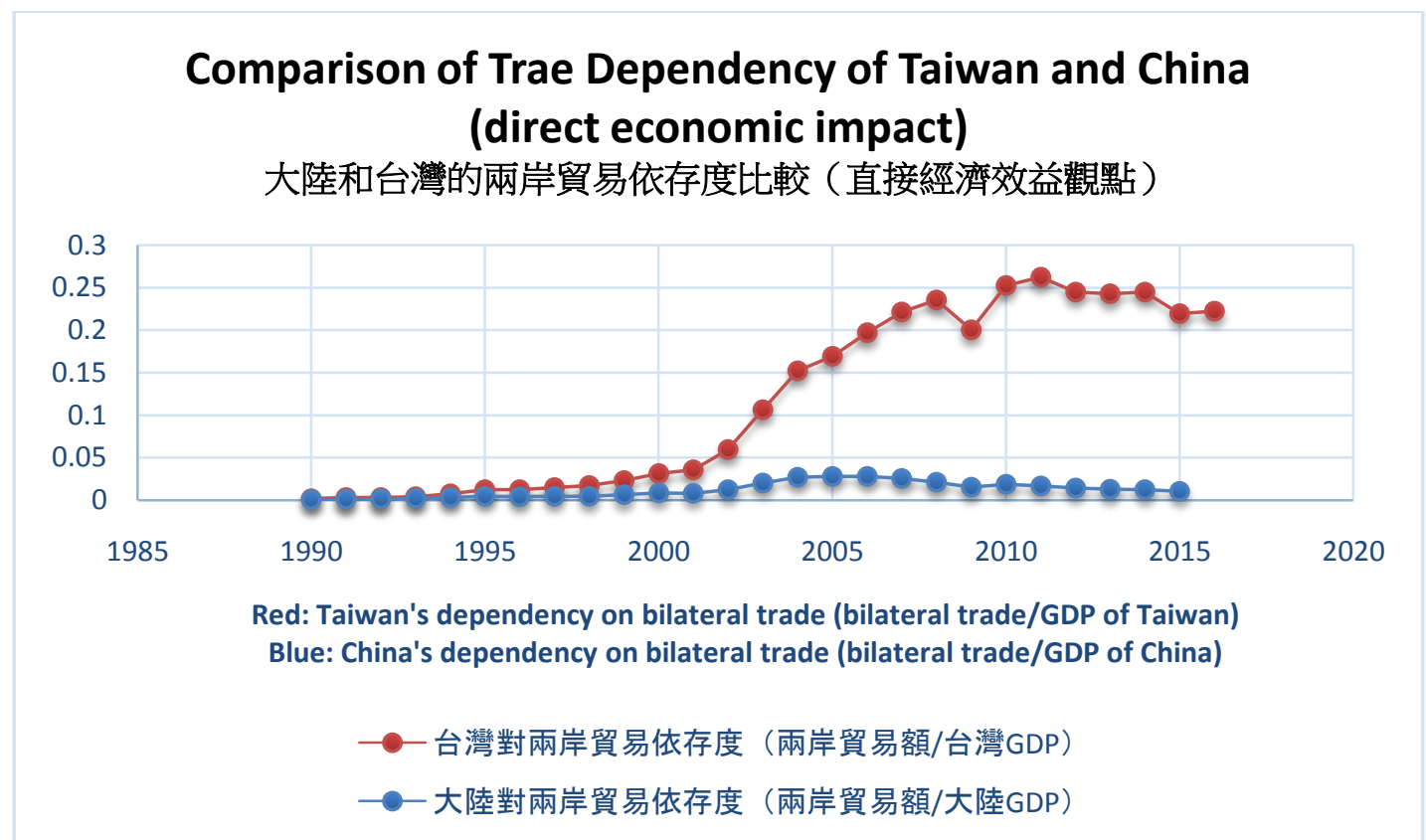

The relative dependency can be calculated by finding the ratios of the trade dependency of the two countries, and based on that calculation; we can see that Taiwan's dependency on bilateral trade is almost 20 times that of mainland China(Figure 15).

Figure 15. Relative Dependency of Taiwan's Economy on that of China

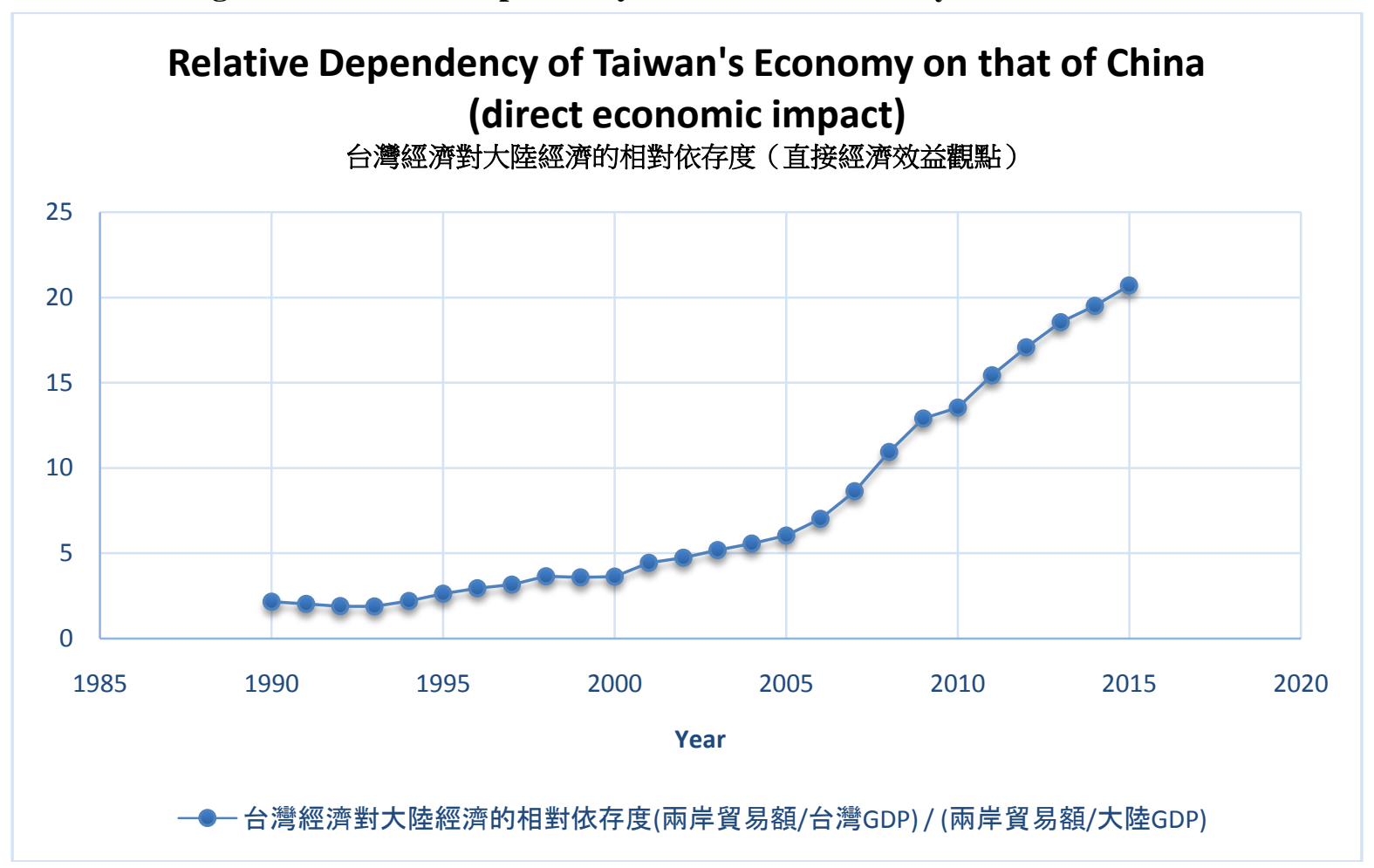

\section{Overall Economic Impact}

We examine the overall economic impact of bilateral trade on the economies of Taiwan and China by looking into the growth volume and growth rate of the two countries. 
Regression coefficients of bilateral trade can be calculated by obtaining the ratios of GDP growth to that of the growth volume of bilateral trade between Taiwan and China (Figure 16).

Figure 16. Regression coefficients of bilateral trade between Taiwan and China

\section{Regression coefficients of bilateral trade} 台灣兩岸貿易迴歸係數

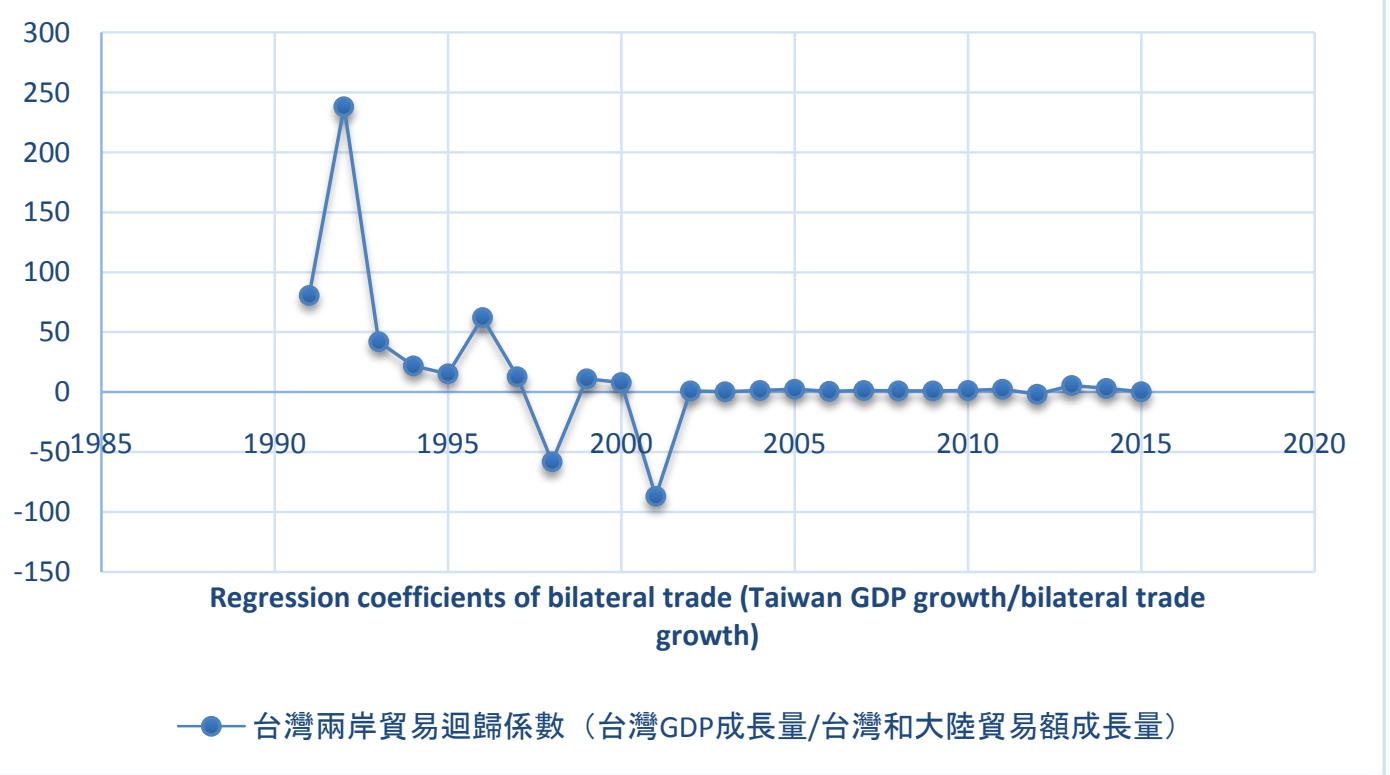

From Figure 16, we can see that the regression coefficients of bilateral trade between Taiwan and China are virtually flat after 2002. The reason for that is, with exception of 1992, 1998, and 2001, growth in volume in Taiwan's GDP and growth in bilateral trade between Taiwan and China are almost directly proportional in their increases, with little fluctuations.

In addition, Taiwan's GDP grew tremendously in 1992, yet the growth in bilateral trade between Taiwan and China did not grow as much, therefore the regression coefficients reached a high point of 238 times (Table 2).

Table 2. Taiwan's GDP Growth (million USD) and Bilateral Trade Growth (USD)

\begin{tabular}{|l|l|l|}
\hline Year & Taiwan's GDP Growth (million USD ) & Bilateral Trade Growth (USD) \\
\hline 1991 & 20,699 & $255,944,227$ \\
\hline 1992 & 35,845 & $150,477,775$ \\
\hline 1993 & 11,981 & $283,596,534$ \\
\hline 1994 & 21,264 & $958,602,150$ \\
\hline 1995 & 22,820 & $1,477,549,209$ \\
\hline 1996 & 13,441 & $215,293,860$ \\
\hline 1997 & 11,072 & $858,544,547$ \\
\hline 1998 & $-23,368$ & $403,377,522$ \\
\hline 1999 & 23,802 & $2,117,919,660$ \\
\hline 2000 & 27,281 & $3,377,547,757$ \\
\hline 2001 & $-31,002$ & $357,536,052$ \\
\hline 2002 & 8,425 & $7,696,956,037$ \\
\hline 2003 & 9,715 & $15,412,751,747$ \\
\hline 2004 & 29,889 & $19,232,777,524$ \\
\hline 2005 & 27,290 & $10,595,846,594$ \\
\hline 2006 & 12,820 & $12,854,095,590$ \\
\hline 2007 & 19,665 & $13,840,022,320$ \\
\hline 2008 & 8,707 & $7,842,971,108$ \\
\hline 2009 & $-24,896$ & $-19,602,733,832$ \\
\hline 2010 & 54,040 & $34,208,889,969$ \\
\hline 2011 & 39,548 & $14,675,523,544$ \\
\hline 2012 & 10,192 & $-5,933,991,100$ \\
\hline 2013 & 15,769 & $2,754,870,853$ \\
\hline 2014 & 18,905 & $5,782,162,073$ \\
\hline 2015 & $-5,323$ & $-14,765,788,482$ \\
\hline & & \\
\hline & & \\
\hline
\end{tabular}


In 1998 and 2001, however, the GDP of Taiwan decreased while the bilateral trade increased, so the coefficients turned to become negative during that time (Figure 17).

Figure 17. Mainland China Trade Regression Coefficient

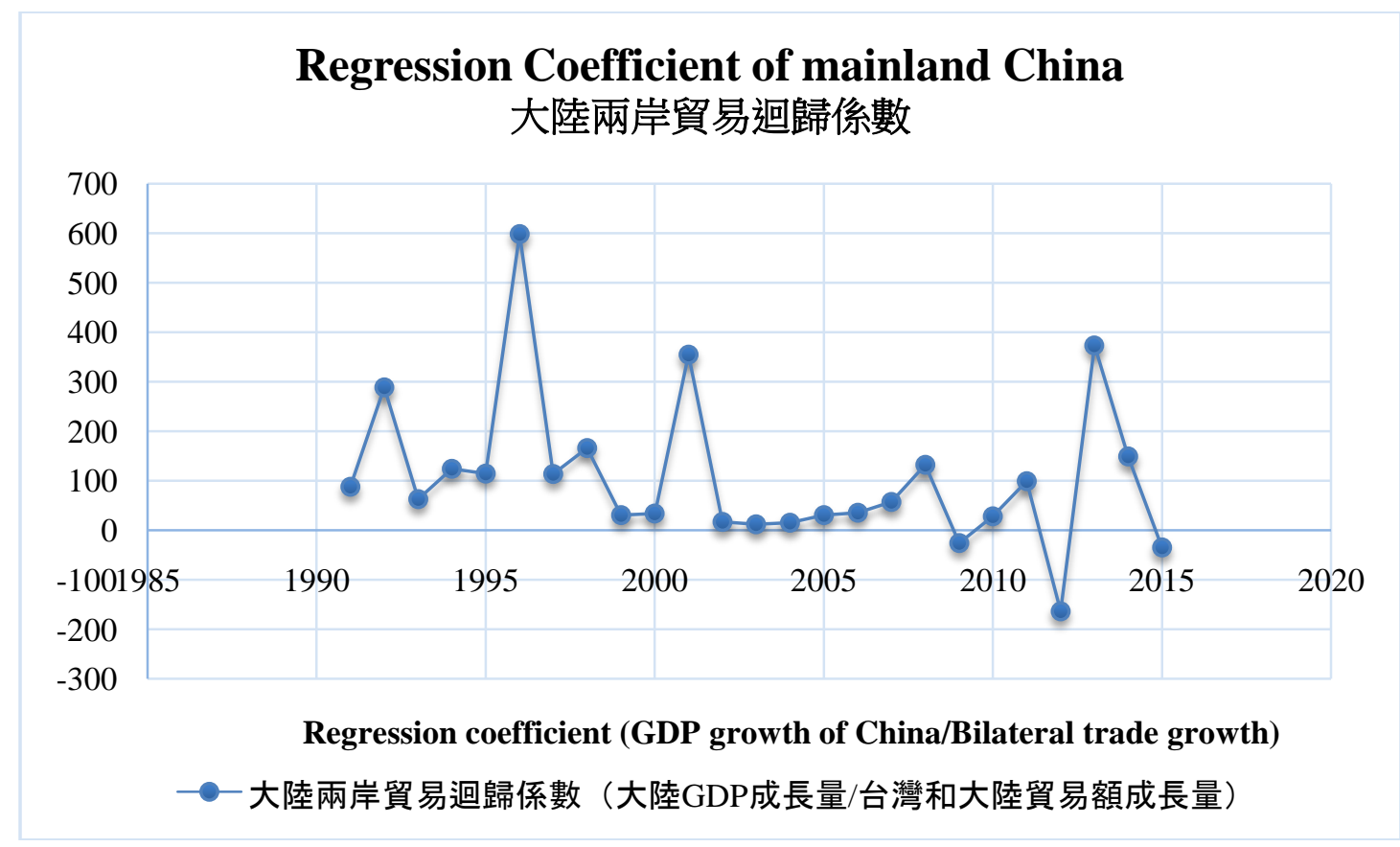

If we compare the regression coefficients of bilateral trade of both sides, we will find that fluctuation is larger on the Chinese side, probably because China's GDP, as the denominator, often experiences larger and unnatural growth volumes (Figure 18).

Figure 18. Comparison of Regression Coefficients of Taiwan and China Comparison of Regression Coefficients of Taiwan and China 兩岸貿易迴歸係數比較

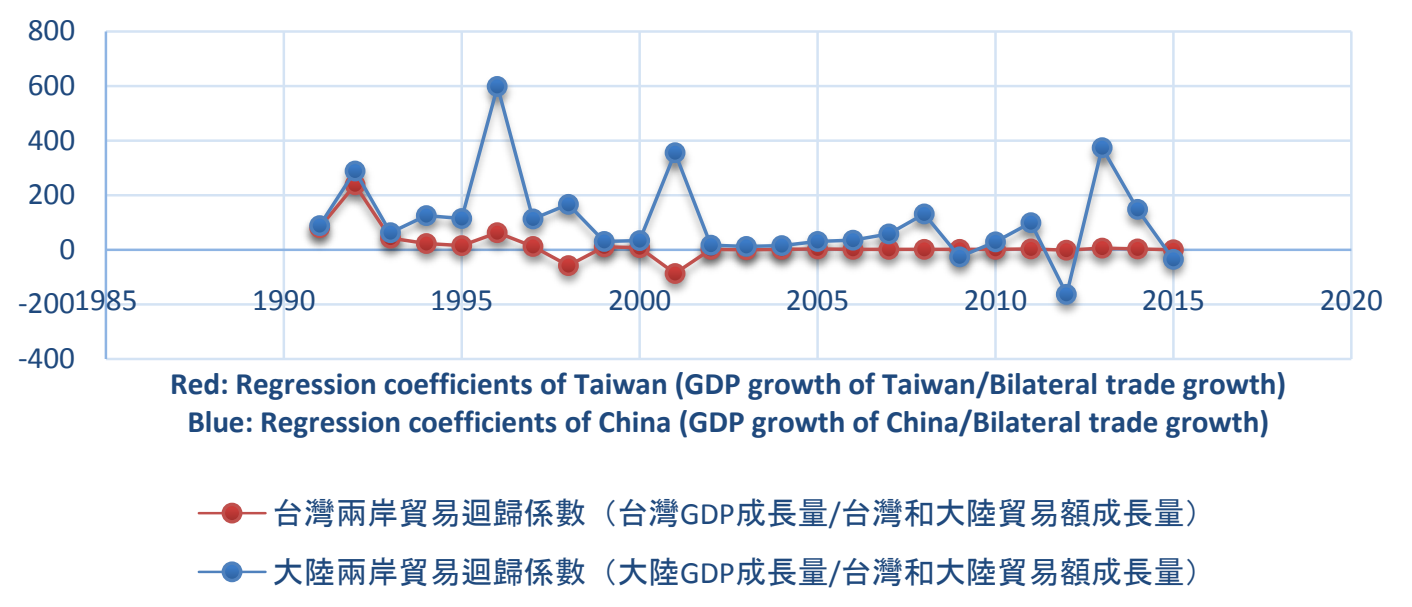

We further examined the trade elasticity by calculating the ratio between GDP growth rate and bilateral trade growth rate, and found the following trends (Figures 19 and 20). 
Figure 19. Taiwan's Bilateral Trade Elasticity

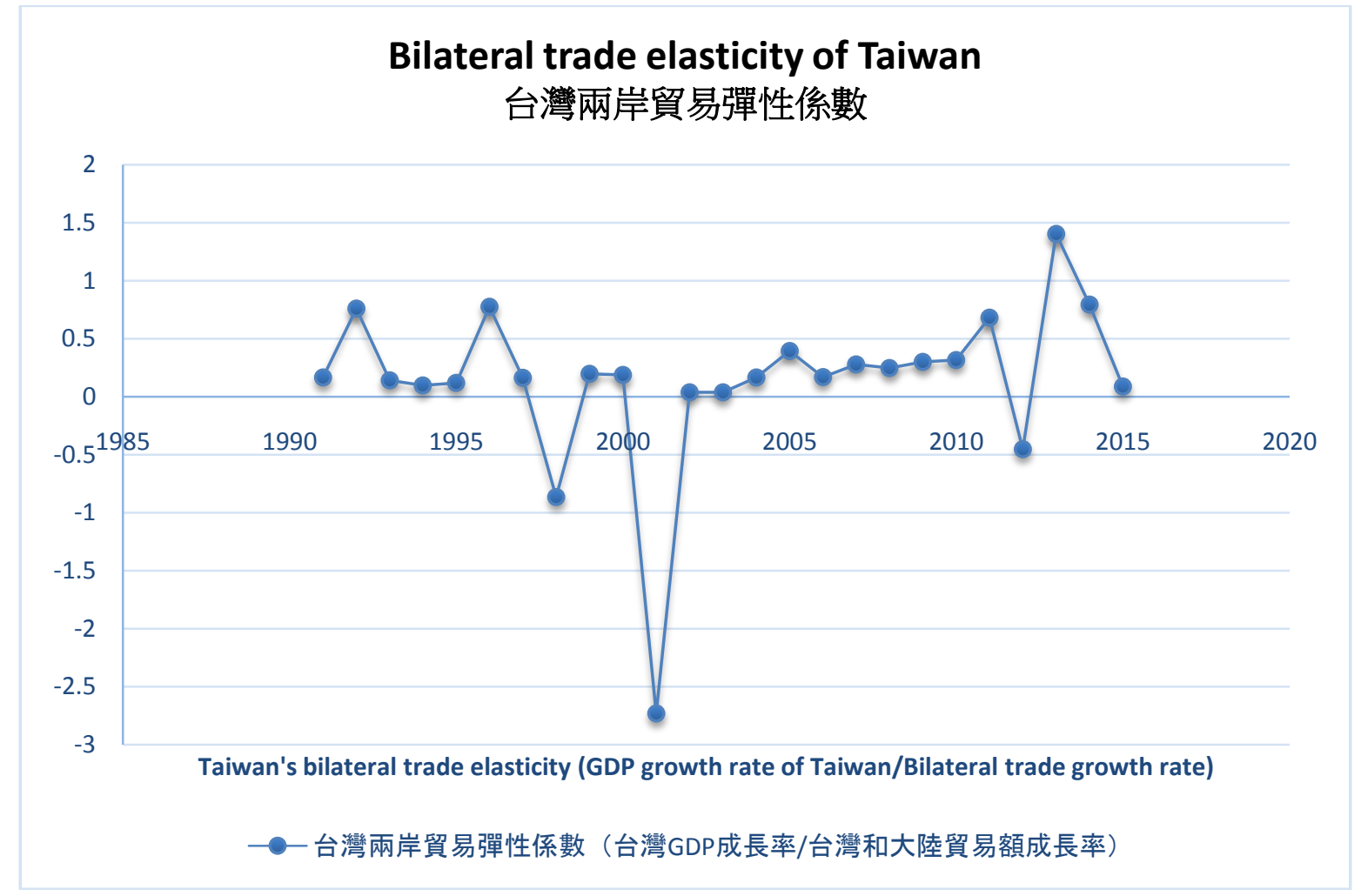

Figure 20. China's Bilateral Trade Elasticity

\section{Bilateral trade elasticity of China 大陸兩岸貿易彈性係數}

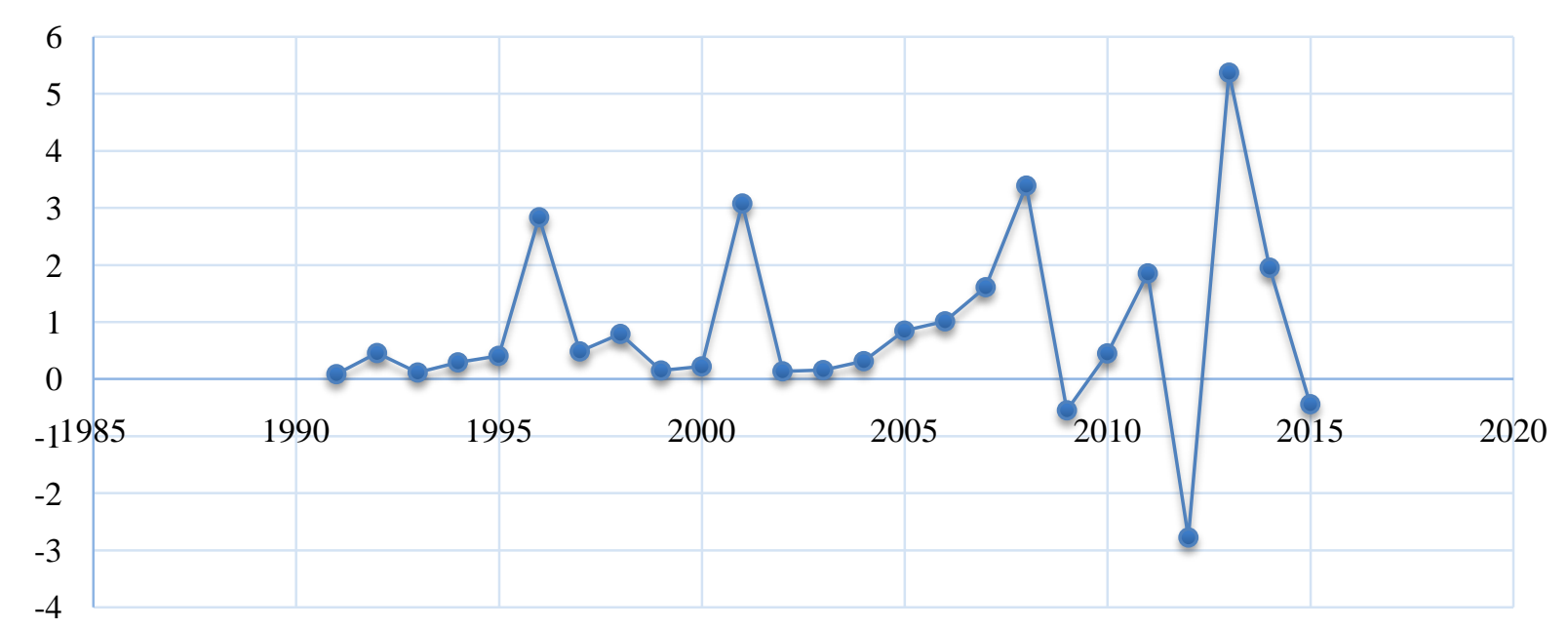

China's bilateral trade elasticity (GDP growth rate of China/Bilateral trade growth rate)

If we compare the relative trends about trades in both countries (Figure 21), bilateral trade regression coefficients and bilateral trade elasticity have similar meaning in the economies, one is a measure of the amount of growth, and the other is a measure of the rate of growth. The trends in the extreme values (peaks or valleys) in the charts are showing similar tendencies as well. 
Figure 21. Comparison of Trade Elasticity of Taiwan and China

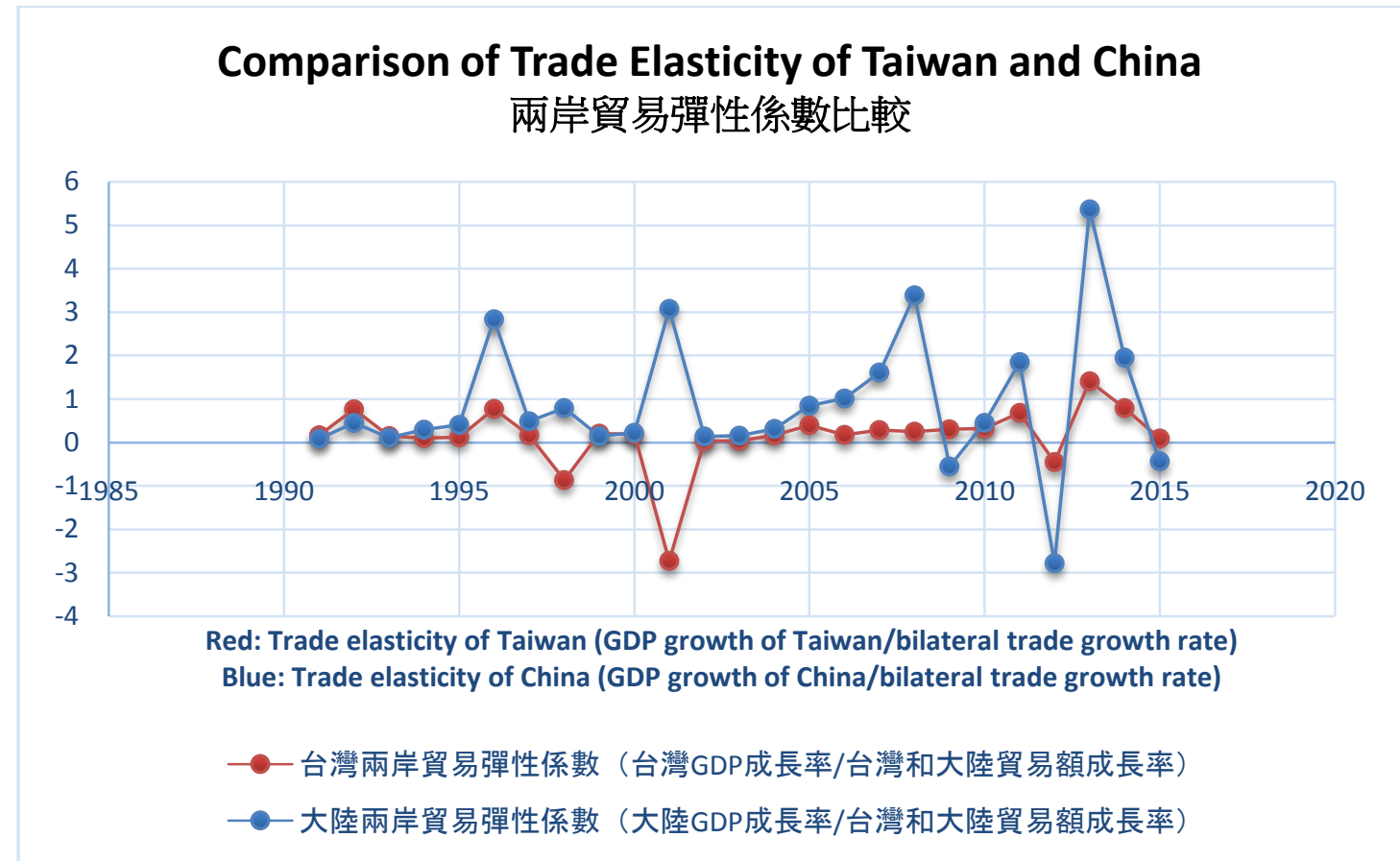

Bilateral trade elasticity is based on previous year's economic output, so it may be a better indicator of the actual changes in trade. Therefore, trade elasticity is preferred in this study.Figure 21 shows a comparison of trade elasticity of Taiwan and China. In economics, cross elasticity measures the responsiveness of the growth rate of one entity (Taiwan or China's GDP growth rate) to a change in the growth rate of another entity (bilateral trade growth rate), ceteris paribus. In this case, it measures the rate of change of GDP of Taiwan or China in response to a $1 \%$ change in the rate of change in the growth rate of bilateral trade between the two. It can be seen that Taiwan and China often times go their separate ways with regard to cross strait trade elasticity, their GDP growth is not much related to the growth in their bilateral trade, or, bilateral trade seems not contributing synchronously to their economic growth.

As well, we calculated the correlation coefficient of trade elasticity of Taiwan and trade elasticity of China, and the correlation is quite low (at 0.144844984). In 1998 and 2001, the correlation were negative, indicating an opposite trends in their respective growth or decline of the two economies.

\section{Cross-strait Overall Trade Dependence}

Based onthe sum of total Taiwanese investment in China and total Chinese investment in Taiwan, mutual investment by both sides of Taiwan Strait can be calculated, and hence the growth rate of the mutual and total investments on each other by the two countries (Table 3 ). 
Table 3. Bilateral investment volume and investment growth rate

\begin{tabular}{|c|c|c|}
\hline Year & Total mutual investment (000’USD) & Total investment growth rate \\
\hline 1990 & 0 & 0 \\
\hline 1991 & 174,158 & 1 \\
\hline 1992 & 246,992 & 0.294884045 \\
\hline 1993 & $3,168,411$ & 0.922045467 \\
\hline 1994 & 962,209 & -2.292851137 \\
\hline 1995 & $1,092,713$ & 0.119431177 \\
\hline 1996 & $1,229,241$ & 0.11106691 \\
\hline 1997 & $4,334,313$ & 0.716393117 \\
\hline 1998 & $2,034,621$ & -1.130280283 \\
\hline 1999 & $1,252,780$ & -0.624084835 \\
\hline 2000 & $2,607,142$ & 0.519481486 \\
\hline 2001 & $2,784,147$ & 0.063576025 \\
\hline 2002 & $6,723,058$ & 0.58588086 \\
\hline 2003 & $7,698,784$ & 0.126737677 \\
\hline 2004 & $6,940,663$ & -0.109228902 \\
\hline 2005 & $6,006,953$ & -0.155438206 \\
\hline 2006 & $7,642,335$ & 0.213989834 \\
\hline 2007 & $9,970,545$ & 0.2335088 \\
\hline 2008 & $10,691,390$ & 0.067422945 \\
\hline 2009 & $7,180,079$ & -0.489035148 \\
\hline 2010 & $14,712,217$ & 0.511964852 \\
\hline 2011 & $14,428,249$ & -0.01968139 \\
\hline 2012 & $13,123,660$ & -0.099407406 \\
\hline 2013 & $9,539,569$ & -0.375707854 \\
\hline 2014 & $10,611,201$ & 0.100990642 \\
\hline 2015 & $11,209,552$ & 0.053378672 \\
\hline 2016 & $9,918,360$ & -0.130182006 \\
\hline
\end{tabular}

In this study, we have designed a new measure of the integrated dependency across Taiwan Strait and the rate of growth of interdependency between the two countries based on data from both bilateral trade and bilateral, mutual investments. The new measure is termed Integrated Bilateral Growth Rate of Interdependency or IBGRI for short.

Integrated Bilateral Growth Rate of Interdependency (IBGRI):

IBGRI = Bilateral Trade Growth Rate*Bilateral Investment Growth Rate

Figure 22. Integrated Bilateral Growth Rate of Interdependency (IBGRI)

\section{Integrated Bilateral Growth Rate of Interdependency 兩岸綜合依存度成長率}

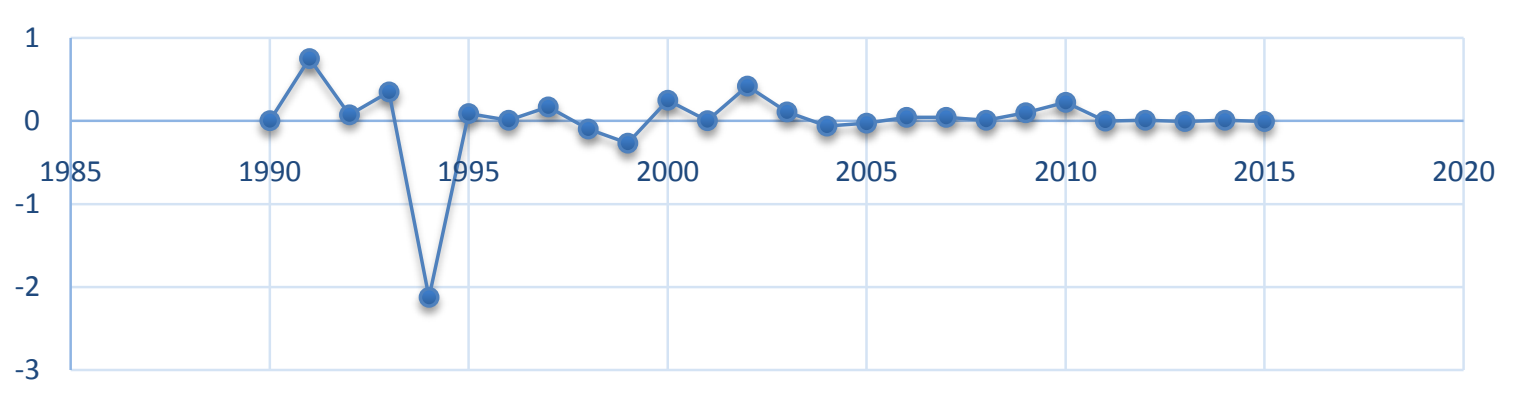

Finally, in this study, we extend beyond the model of Wang et al. (2013)of bilateral trade elasticity index and modified the formula by replacing the denominator of bilateral trade growth rate with Integrated Bilateral Growth Rate of Interdependency (Figure 22), so as to gauge and estimate, respectively, the elasticities of integrated bilateral growth rate of interdependency on China and Taiwan. 
This new measure seems to be able to better explicate the intricate nature of the trade relations and interdependencies of China and Taiwan, given the complex nature of geopolitical factors affecting the two governments across the Taiwan Strait (Figure 23).

Figure 23. Integrated Bilateral Elasticity of Interdependency (IBEI)

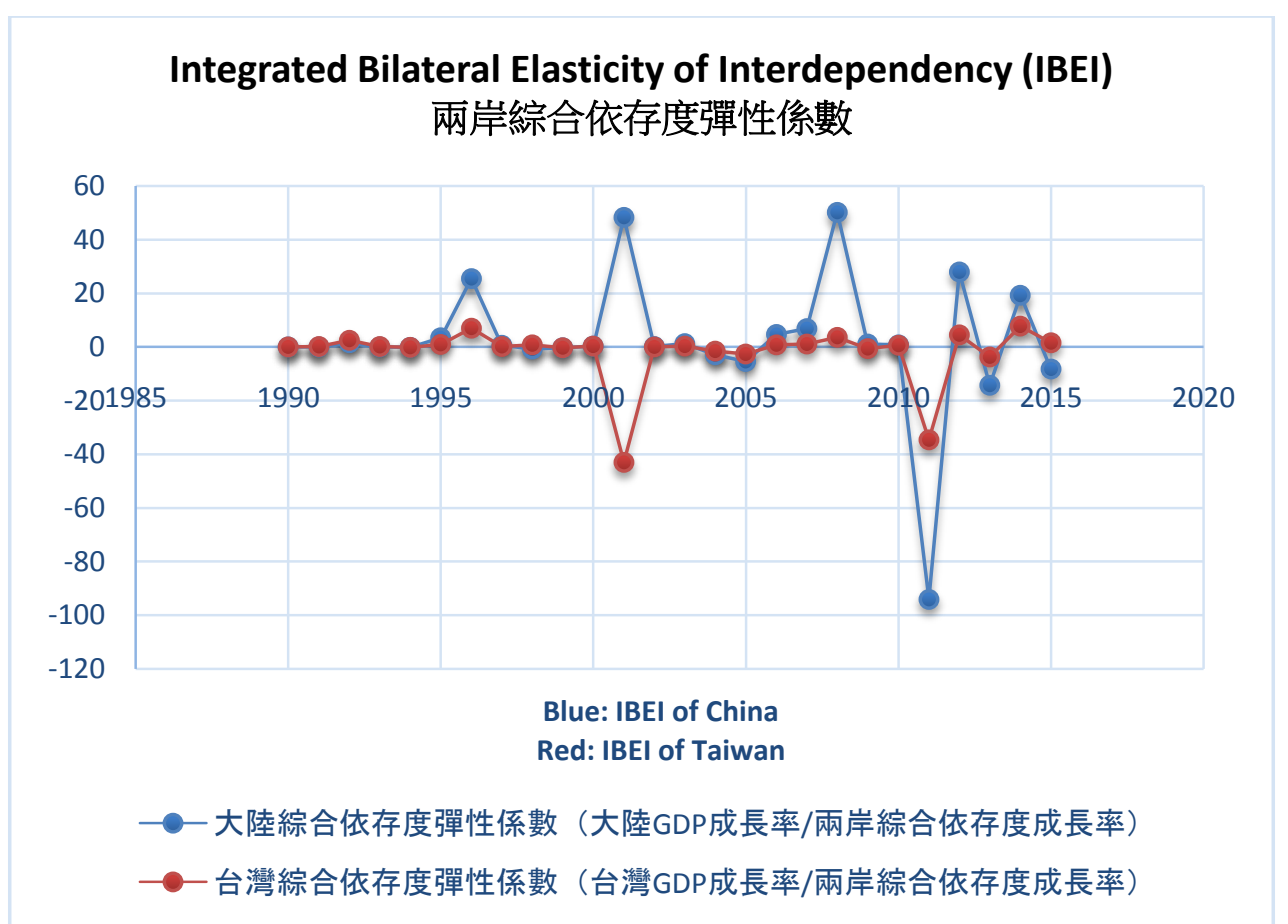

Since the Integrated Bilateral Interdependency comprises both the bilateral trade growth rate and bilateral investment growth rate, and the two are not always moving in the same direction. For example, even though bilateral investment on each other reduced by a large margin, yet the bilateral trade volume increased tremendously. Therefore, the integrated bilateral elasticity of interdependency is better used as a way to observe the degree of drastic changes in bilateral trade, and not a good measure of the absolute trend, either positive or negative in bilateral trade relations.

Integrated Bilateral Elasticity of Interdependency (IBEI):

$$
\text { IBEI }=\text { GDP growth rate/growth rate of integrated bilateral interdependency }
$$

Based on our analysis, Taiwan's elasticity index on integrated bilateral trade interdependency fluctuates smaller, indicating that the GDP of Taiwan is more susceptible to the variations, restrictions, and impacts of the integrated interdependency than the GDP of China is. Therefore, based on our analyses, we can tentatively conclude that, in general, Taiwan suffers from a higher level of dependency (inan integrated manner) on the trade relationship between the two entities across Taiwan Strait (Figure 23).

\section{Conclusions}

In this study, we have found that Taiwan's dependency on bilateral trade with China has grown from less than $1 \%$ in 1990 to $23 \%$ in 2015, and this dependency on export trade is even more significant, at approaching 30\%. On the other hand, China's dependency on bilateral trade with Taiwan has not seen much growth over the years, and saw a decline since 2005, and the dependency dropped to about only $1 \%$ in 2015. In another word, Taiwan's level of dependency on bilateral trade between China and Taiwan is almost 20 times that of China. We have also measured in this study the interdependency on mutual investment. China's dependency on Taiwanese investment in 2005 has decreased to the level of the 1990's, and this result is the same as China's dependency on bilateral trade, both have a downward trend. The reason for that is not a decrease in Taiwanese investment in China, but because China has started to attract investment from other regions of the world. 
On the part of Taiwan, even though the overall capital pool of Taiwan is relatively small, but Taiwan's dependency on Chinese investment is, on average, not as much as China's dependency on investment by Taiwanese businesses. We have also measured the trade elasticities of both China and Taiwan. We measured the situation of how much would the GDP of Taiwan or China change in accordance with changes in the growth rates of trade between China and Taiwan. Our results indicate that the bilateral trade elasticities of Taiwan and China have a correlation coefficients of 0.14 ; and, if we observe the peaks of the function curve, we find that even though the peak indexes could point at the same directions from time to time, they could be in the opposite directions as well (such as in 2001). Therefore, it is not feasible for us to conclude that the cross elasticity of Taiwan and China could have any positive or negative correlations, let alone any causal relationships.

In addition, Taiwan's elasticity on integrated bilateral interdependency fluctuates relatively smaller, therefore it is concluded that overall, Taiwan's dependency on integrated bilateral trade and economic relations is relatively higher than that of China.

Acknowledgement: Taiwan Fellowship provides funding of this study. During the fellowship period in the summer of 2017, the first author was a Visiting Scholar at the Center of Public Economic Policy Studies at National Taiwan University. The authors acknowledge the financial support of the Ministry of Foreign Affairs of Republic of China (Taiwan) for this study.

\section{References}

Abdelal, Rawi (2004), "Interpreting Interdependence: National Security and the Energy Trade of Russia, Ukraine, and Belarus." In Swords and Sustenance: The Economics of Security in Belarus and Ukraine, edited by Robert Legvold and Celeste Wallander, 101-127. Cambridge, MA: MIT Press, 2004.

Aggarwal, Vinod K. and Koo, Min Gyo (2008), Asia's New Institutional Architecture: Evolving Structures for Managing Trade, Financial, and Security Relations, The Political Economy of the Asia Pacific, pp 1-34.

Blanchard, Jean-Marc F. and Ripsman, Norrin M. (1996), Measuring economic interdependence: A geopolitical perspective, Geopolitics and International Boundaries, 1 (3): 225-246.

Blanchard, Jean-Marc F. and Mansfield, Edward D. and Ripsman, Norrin M. (2007), The political economy of national security: Economic statecraft, interdependence, and international conflict, Security Studies, Volume 9, 1999 - Issue 1-2, Pages 1-14.

Bobrow, Davis B. and Kudrle, Robert T (1994), Economic Interdependence and Security: U.S. Trade and Investment Policy for a New Era, Minnesota Journal of Global Trade, 61 (1994).

Buszynski,Leszek (2009), Sino-Japanese Relations: Interdependence, Rivalry and Regional Security, Contemporary Southeast Asia: A Journal of International and Strategic Affairs, Volume 31, Number 1, April 2009, pp. 143-171.

Chen, Bozhi(陳博志) (2017), “Economic Policy Decision Making in Taiwan”, in the Proceedings of the 2017 Sino-US Relations and Taiwan's Future Workshop, July 29, 2017, at National Taiwan University, Taipei, Taiwan, ROC.

Chung Hwa Economic Research Institute (2009) (in Chinese), Evaluation on the Impact of Bilateral Service Trade Agreement on Taiwan's Economy and Industries. (中華經濟研究院(2009), 兩岸洽簽服務貿易協議對我總體經濟及產業之影響評估.)

Chen, Tianzhi (2003) (In Chinese), Globalization and Bilateral Economic Relations, Journal of Economic Theses, 31(3), 331-345. (陳添枝(2003), 全球化與兩岸經濟關係, 經濟論文叢刊, 31(3), 331-345.)

Copeland, D.C. (1996), Economic Interdependence and War: A Theory of Trade Expectations, International Security, Spring 1996, Vol. 20, No. 4, Pages 5-41.

Cossa, Ralph A. and Khanna, Jane (1997), East Asia: Economic Interdependence and Regional Security, International Affairs (Royal Institute of International Affairs 1944-), Vol. 73, No. 2, Asia and the Pacific (Apr., 1997), pp. 219-234.

Crescenzi, Mark J. C. (2002), Economic Interdependence and Conflict in World Politics, University of North Carolina, Chapel Hill.

Finona, Dominique and Locatellib, Catherine (2008), Russian and European gas interdependence: Could contractual trade channel geopolitics? Energy Policy, Volume 36, Issue 1, January 2008, Pages 423-442. 
Freedom Times (2017) (in Chinese), CCP's Conspiracy of Using 5\% of Taiwanese to Subdue Taiwan. (自由时报 (2017), 中共挟 5\%制服台湾的大阴谋曝光.)

Gasiorowski, Mark J. (1986), Economic Interdependence and International Conflict: Some Cross-national Evidence, International Studies Quarterly, Volume 30, Issue 1Pp. 23 - 38.

Gomez, David Matesanz, Torgler, Benno and Ortega, Guillermo J. (2013), Measuring Global Economic Interdependence: A Hierarchical Network Approach, The World Economy, 36 (12): 1632-1648.

Kahler, M., \&Kastner, S. L. (2006). Strategic uses of economic interdependence: Engagement policies on the Korean Peninsula and across the Taiwan Strait. Journal of Peace Research, 43(5), 523-541.

Keshk, O. M. G., Pollins, B. M. and Reuveny, R. (2004), Trade Still Follows the Flag: The Primacy of Politics in a Simultaneous Model of Interdependence and Armed Conflict. Journal of Politics, 66: 1155-1179.

Maoz, Z. (2009), The Effects of Strategic and Economic Interdependence on International Conflict Across Levels of Analysis. American Journal of Political Science, 53: 223-240.

Mastanduno, Michael (1999), Economic statecraft, Interdependence, and national security: Agendas for research, Security Studies, Vol. 9 ,Iss. 1-2,1999.

McMillan, Susan M. (1997), Interdependence and Conflict, Mershon International Studies Review, Volume 41, Issue Supplement 1Pp. $33-58$.

Pevehouse, Jon C. (2004), Interdependence Theory and the Measurement of International Conflict, Journal of Politics, Vol. 66, No. 1. (1 February 2004), pp. 247-266.

Skaperdas, Stergios and Syropoulos, Constantinos (2001), Guns, Butter, and Openness: On the Relationship between Security and Trade, The American Economic Review, Vol. 91, No. 2, Papers and Proceedings of the Hundred Thirteenth Annual Meeting of the American Economic Association (May, 2001), pp. 353357.

Tellis, Ashley J. and Wills, Michael (2007) Editors, Trade, Interdependence, and Security - - Google Books.

Wang, Hua, Lijuan Deng, and Qin Fan (2013) (in Chinese), "Concept and measurement of bilateral economic interdependence between Taiwan and China, Taiwan Studies Series, 126, 49-60. (王華,鄧利娟,范芹(2013), 兩岸經濟相互依存的概念與度量方法, 台灣研究集刊, 第126期 49-60.)

Wang, Hua and Yonghong Tang (2010) (in Chinese), Taiwanese Investment, Bilateral Trade and Economic Growth---a systematic way of measuring the economic interdependence between China and Taiwan, Global Economy and Trade Explorations, 26(6)，38-44. (王華，唐永紅(2010)，台商投資， 兩岸貿易與經濟增長——對於兩岸經濟相互依存性的系統度量，國際經貿探索，第26卷第6期 3844.) 